\title{
Reinforcement bars tying types in reinforced concrete
}

\author{
Marawan Hamid ${ }^{1, *}$, Ali Joudah ${ }^{1}$, Alyaa Mohammed $^{1}$ \\ ${ }^{1}$ University of Technology, Baghdad, Iraq
}

\begin{abstract}
In huge reinforced concrete structures, it is often difficult to distribute the reinforcing bars, especially at the connection regions, to keep the spacing between bars within the minimum acceptable limits as recommended in the global specifications standard, by using the common methods such as, overlapping or welding, therefore, a new method for bonding was introduced, using mechanical joints and electro fusion bonding method, and comparing these methods with the maximum strength of reinforcing bars without joints and the failure location within maximum strength limits outside the joints.
\end{abstract}

\section{Introduction}

While constructing structures with huge concrete frames, especially within the construction stage, the structural engineer faces some difficulties in applying the structural plans prepared by the designers based on the global specifications standard, because of the minimum limits for spacing between reinforcing bars. Therefore, the constructing engineer and his technical team must follow other procedures than overlapping or welding such as mechanical joints or electro fusion bonding methods. The solution is connecting and overlapping between the steel bars in different ways and different factors will affect this like the reinforced steel bar diameter, quantity of the reinforcement steel, grade of steel and high compressive strength of concrete.

\section{Objectives}

The main objective of this research is to investigate the optimum connection between steel bars reinforcement connection such as mechanical connection or butt welding in heavy structure sections.

\section{Research significance}

The knowing of deferent type steel bars reinforcement connection and when we can use it on deferent member in structure to give more surety according to the tests from this study.

\section{Types of tying and overlapping between steel bars: Tying by overlapping between steel bars}

Splicing by wire: is a simple and common way, give the user flexibility in the work so that he can separate the steel (before pouring) whenever he wants, as shown in figure 1. Formation depends on reinforced steel diameter, steel grade, compressive strength of concrete, the lap length between pieces is according to the following table 1 and plate 1 .

Table 1. Overlap in steel bar by splicing by wire

\begin{tabular}{|c|c|c|c|c|c|}
\hline \multirow{2}{*}{ Bar Type } & \multicolumn{5}{|c|}{ Concrete Strength grade } \\
\cline { 2 - 6 } & C20 & C25 & C30 & C35 & $>$ C40 \\
\hline HPB 235 & $31 \mathrm{~d}$ & $27 \mathrm{~d}$ & $24 \mathrm{~d}$ & $22 \mathrm{~d}$ & $20 \mathrm{~d}$ \\
\hline HPB 335 & $39 \mathrm{~d}$ & $34 \mathrm{~d}$ & $30 \mathrm{~d}$ & $27 \mathrm{~d}$ & $25 \mathrm{~d}$ \\
\hline HPB 400 & $46 \mathrm{~d}$ & $40 \mathrm{~d}$ & $36 \mathrm{~d}$ & $33 \mathrm{~d}$ & $30 \mathrm{~d}$ \\
\hline
\end{tabular}

- (d) the diameter for steel bar

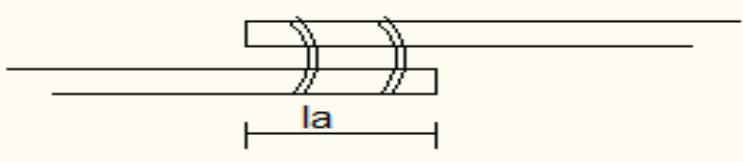

Plate 1. Shows the distance of (la) 

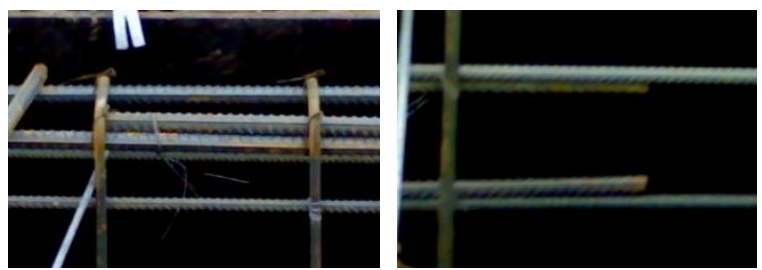

Fig. 1. Splicing by wires

Tying by welding: this type is used for strong steadiness in the structural parts wherein the steel reinforcement network is subjected to movement during the work or if the design requirements assume that. Like reinforcement of columns, retaining walls and Pile reinforcement. For example: in the situation of pouring long piles, after the completion of excavation, the steel box is installed first before pouring concrete, the steel box is installed by pieces and each piece is welded with another one. Using the previous method, the wire between steel pieces will not bear the heavy weight of the steel box and will get separated, thus, welding is used in this scenario. See Figure 2.

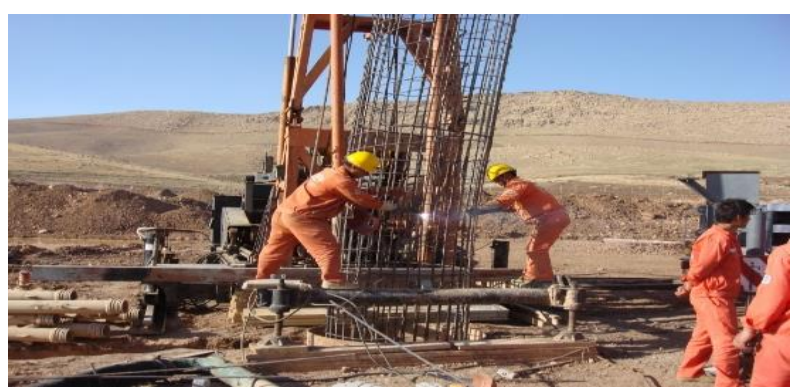

Fig. 2. Shows a steel cage for piling

In case of welding, the type of welding wire should be taken into account so that the cooling process happens gradually for the welded pieces:

\subsection{Welding}

\subsubsection{Welding one side of the steel bar}

Shown in plate 2, 3 and figure 3.
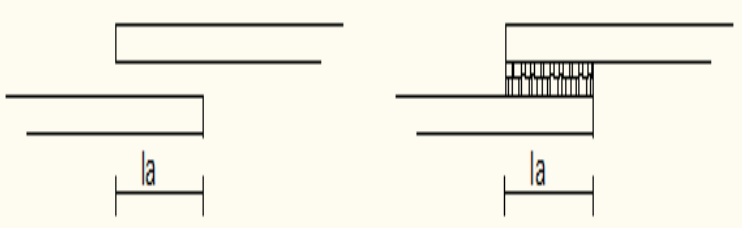

Plate 2. Shows both the faces of steel bar welding

Where: $1 \mathrm{a}=10 * \mathrm{~d}[1]$

(d) diameter for steel bar
* sometimes welding one side of the steel bar equals to $\left(1 \mathrm{a}=15^{*} \mathrm{~d}\right)$.

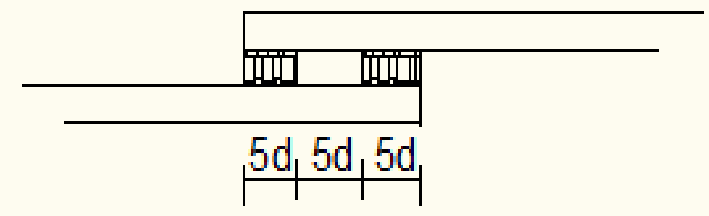

Plate 3. Shows the welding one side of the steel bar equal to $15 * d$

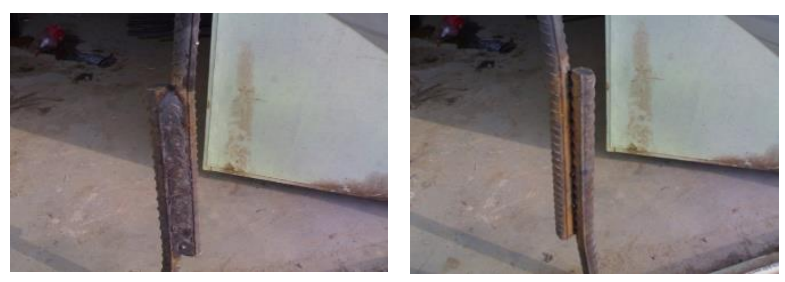

Fig. 3. Shows welding one side of the steel bar and the other side without welding

\subsubsection{Welding for two sides}

Welding distance for two sides is less than the distance for welding one side but in this case a consideration should be given for modulus of elasticity of steel as welding two sides will cause melting locations behind the welding part and also cooling these locations when they get in contact with the surrounding air thus, reducing modulus of elasticity in it.as shown in plate 4 and plate 5 .

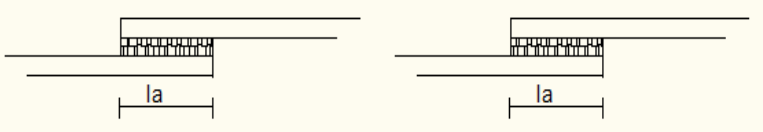

Plate 4. The front and back face for welding two sides of steel bar

Where: $1 \mathrm{a}=5 * \mathrm{~d}[1]$

(d) Diameter for steel bar

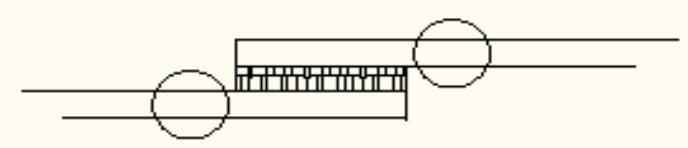

Plate 5. The area that are put in a circle show the weaken points

Tensile tests were performed for these two types of welding (one side and two sides) and the results were successful as no failure occurred in the connection area or it is surrounding, and as shown in figure 4 and according to the attached table 2, which represents the average of six samples that were taken for testing with different diameters. 
Table 2. Results for testing steel bars were welding together by two ways for connect

\begin{tabular}{|c|c|c|c|c|}
\hline \multirow{2}{*}{$\begin{array}{c}\text { Nominal } \\
\text { steel } \\
\text { bar } \\
\text { diameter } \\
(\mathbf{m m})\end{array}$} & \multicolumn{2}{|c|}{$\begin{array}{c}\text { Single side lap } \\
\text { welding }\end{array}$} & \multicolumn{2}{c|}{$\begin{array}{c}\text { Double side lap } \\
\text { welding }\end{array}$} \\
\cline { 2 - 5 } & $\begin{array}{c}\text { Yield } \\
\text { strength* } \\
\left(\mathrm{f}_{\mathrm{y}}\right)\end{array}$ & $\begin{array}{c}\text { Tensile } \\
\text { strength } \\
\left(\mathrm{f}_{\mathrm{t}}\right)\end{array}$ & $\begin{array}{c}\text { Yield } \\
\text { strength* } \\
\left(\mathrm{f}_{\mathrm{y}}\right)\end{array}$ & $\begin{array}{c}\text { Tensile } \\
\text { strength } \\
\left(\mathrm{f}_{\mathrm{t}}\right) \\
(\mathrm{MPa})\end{array}$ \\
\hline 25 & 430 & 585 & 440 & 590 \\
\hline 22 & 430 & 570 & 430 & 570 \\
\hline 20 & 445 & 585 & 440 & 585 \\
\hline 18 & 425 & 560 & 430 & 570 \\
\hline 12 & 435 & 590 & 425 & 580 \\
\hline
\end{tabular}

* tested steel bars reinforcement conformed to requirements of grade $60(60 \mathrm{ksi})$, min fy=420 MPa, min. min. elongation $=9 \%$ according to

ASTM A 615 -05[2] for bars dai. $12 \mathrm{~mm}, 18 \mathrm{~mm}, 20 \mathrm{~mm}$, $22 \mathrm{~mm}$ and $25 \mathrm{~mm}$.

\section{Materials and experimental work}

The steel bars ore samples of Turkey made with various diameters of bars reinforcement $(20,22,25$ and $32 \mathrm{~mm})$ were taken as the most commonly used in large concrete and heavy reinforcement sections. These sections were subjected to tensile and compressive strength testing in the laboratories of MAS International Investment Company / Iraq Sulaymaniyah and its comparison with the strain of submission and elongation allowed within the standard specifications of the manufacturer of reinforcing steel, the types of linkage conducted within this work are detailed mechanical bonding and butt welding.

\subsection{Butt welding}

It is an economic method and is used in the areas with heavy reinforcements (bridge with high loads): so that the distance between reinforced steel is the minimum distance while when using other type of steel welding, we can't get the adequate distance between the reinforced steel.as shown in plate (6) and Figure 4.
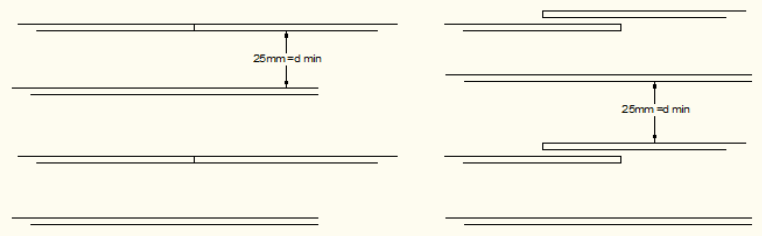

Plate 6. Shows the difference between type one and the butt welding
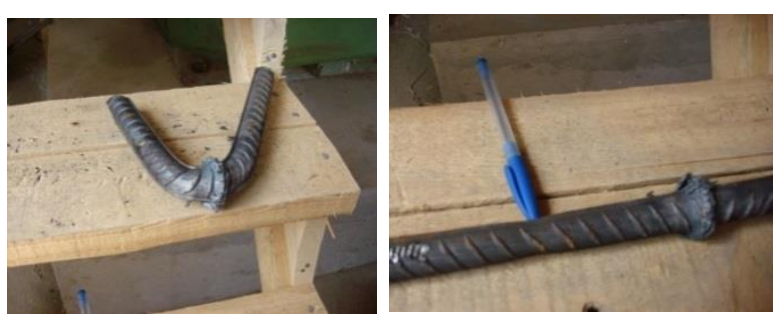

Fig. 4. Shows the joint in the butt welding

Welding between two pieces of steel is done by special equipment that forms a cathode for the first one and electrode for the second one and when connecting between the two, an electrical discharge occurs between the two poles and steel melts and then welding takes place. Tensile test was performed for this type of welding and it was found successful as no failure in the welded area or it's nearby had occurred and also Yield strength test was performed as shown in Figure 4 and according to Table 3 that shows results for six testing samples with different diameters.

Table 3. The result for steel bar connected with butt welding

\begin{tabular}{|c|c|c|c|}
\hline $\begin{array}{c}\text { Nominal steel } \\
\text { bar diameter } \\
(\mathbf{m m})\end{array}$ & $\begin{array}{c}\text { Yield } \\
\text { strength* } \\
\left(\mathbf{f}_{\mathbf{y}}\right) \mathbf{( M P a )}\end{array}$ & $\begin{array}{c}\text { Tensile } \\
\text { strength } \\
\left(\mathbf{f}_{\mathbf{t}}\right) \mathbf{( M P a )}\end{array}$ & Elongation \\
\hline 25 & 450 & 620 & 0.00244 \\
\hline 20 & 455 & 590 & 0.00229 \\
\hline 18 & 420 & 580 & 0.00247 \\
\hline 12 & 525 & 610 & 0.00263 \\
\hline
\end{tabular}

* tested steel bars reinforcement conformed to requirements of grade 60 (60 ksi), min fy $=420 \mathrm{MPa}$, min. min. elongation $=9 \%$ according to ASTM A 615 -05[2] for bars dai. $12 \mathrm{~mm}, 18 \mathrm{~mm}$, $20 \mathrm{~mm}$ and $25 \mathrm{~mm}$.

This method is used outside the forms and not like the previous ones which means the steel should be welded before installing it into the structure as shown in plate 7 and figure 5 and 6.
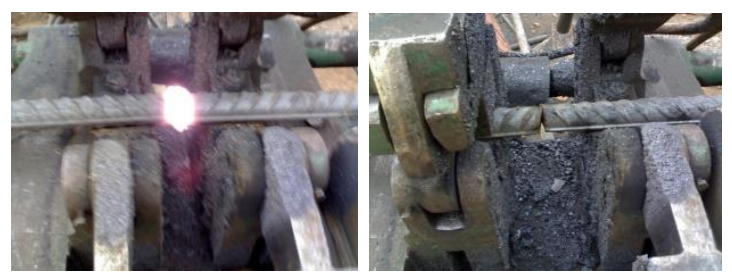

Fig. 5. Shows how to connect in the butt welding spark

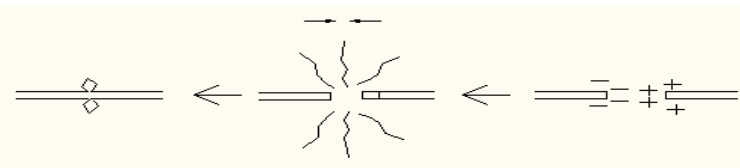

Plat 7. Shows the interaction with the emission of heat and
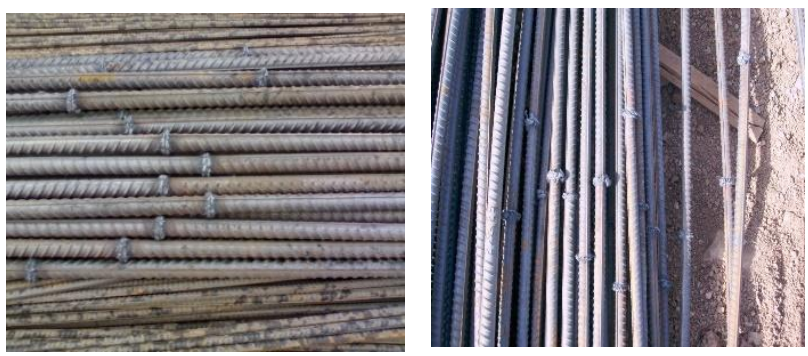

Fig. 6. Shows steel bars stacks 


\subsection{Mechanical joint}

It a new method that has been used for almost 15 years now. It is used for reinforcement diameter of more than (a $20 \mathrm{~mm}$ ). This method depends on welding on friction force between the steel (the same as in galvanised steel pipes), Plate 8.

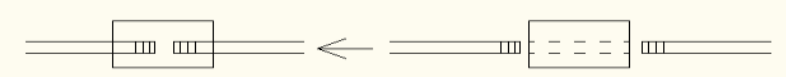

Plat 8. Tying two pieces of steel bars by mechanical joint

This method is used in different places like foundations, columns, beams and walls, where it is on a large distance and is difficult to use the previous welding and connecting methods, especially in embedded reinforcement steel bar as shown in Figure 7 and 8 and Plat 9.

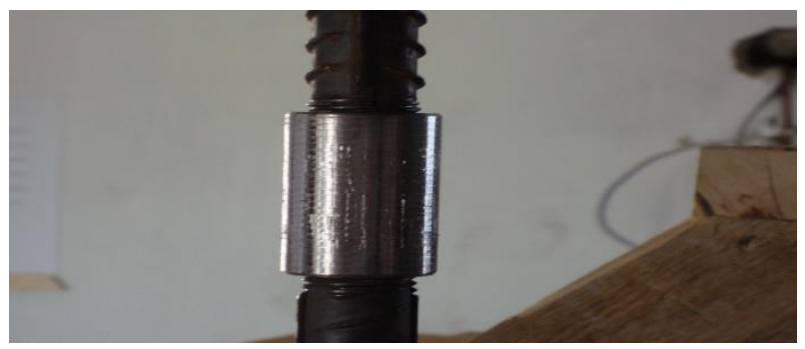

Fig. 7. Shows mechanical joint

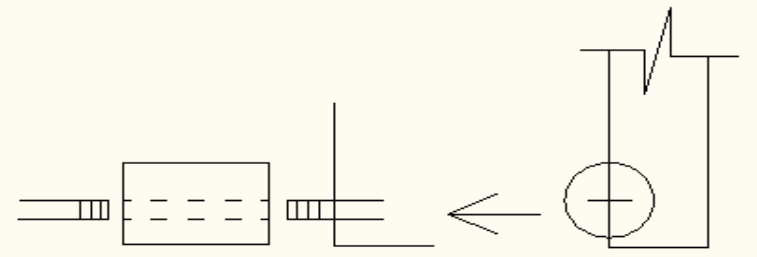

Plate 9. Shows embedded reinforcement steel bar

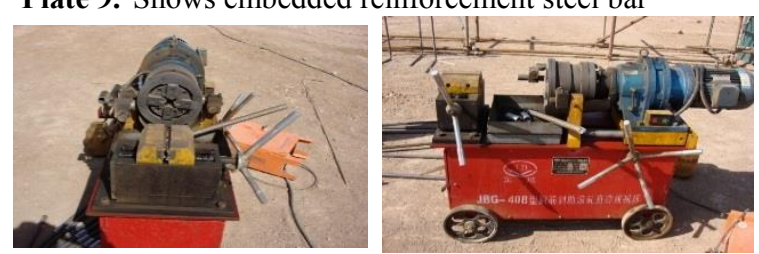

Fig.8. the machine that make the mechanism of mechanical joint
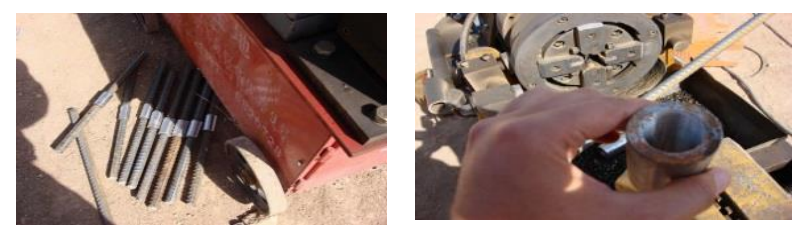

Fig. 9. The production by the machine

Procedure to produce the mechanical joint from the steel bars:

Outside the structure (form) the machine starts cleaning the bump in the reinforced steel in the area where the serrated part is wanted in an automatic way (depending on the bar diameter), Figure 10.
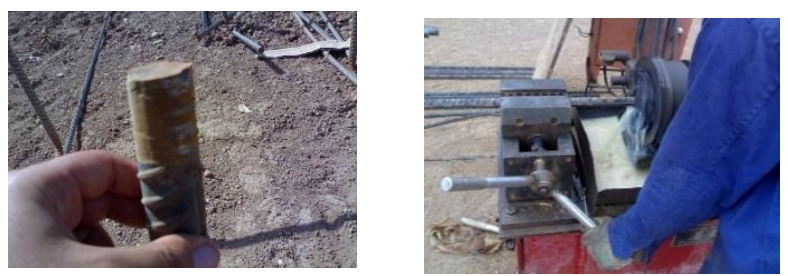

Fig. 10. The machine at the work

And then making serrated in a cone shape (the angle is very small) Figures 11 and 12.
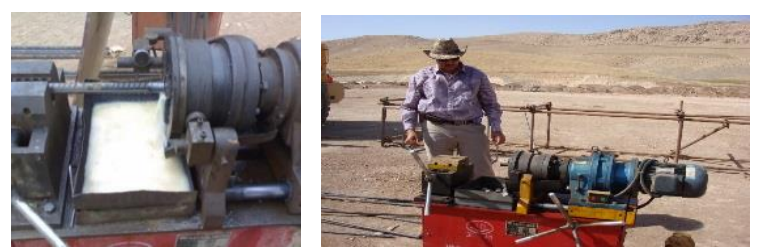

Fig. 11. Shows the machine at work
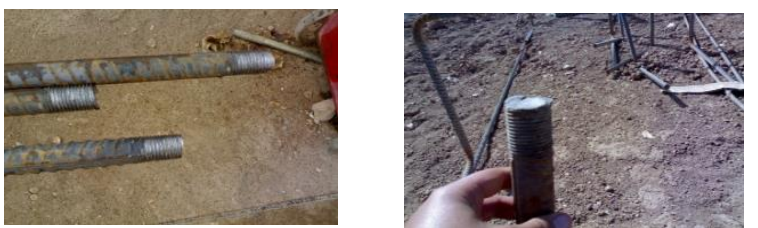

Fig. 12. Shows the steel bar after making it serrated

Tensile tests for several mechanical joint samples have proved the possibility of using the technique. It was found that this welding has the same normal yield stress for steel and the same compression even in the structures that have dynamic loads and vibrations and it was widely used in the United States, Germany, and China. Also, this type of welding was used in Kurdistan /Iraq in the cement factories and in all the fields of foundations, columns, bridges, walls and ceilings, and has proved its creditability in both lab and field tests as several samples were taken directly and without modification for testing for this type of welding for the purpose of this testing as it's shown in Figure 13. The result was successful as no failure occurred in the welded area or its surroundings (Table 4) shows average results for six samples that was taken for testing for different diameters. 

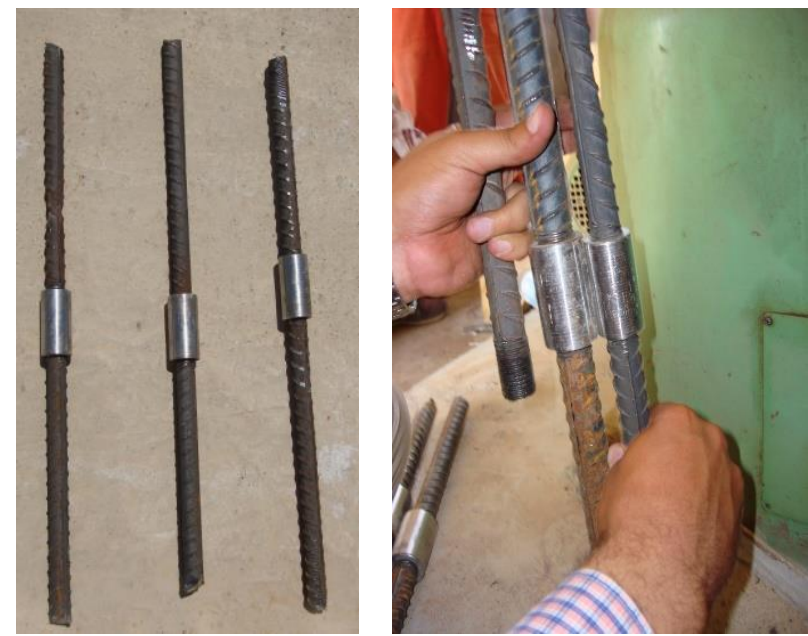

Fig. 13. Shows the steel bar that connected with mechanical joint after tasted in the laboratory

In Germany steel is made in different way as the nut is fixed in the bar from the factory (poured with it) directly and according to the DIN standard) each type is according to the location of the steel bar if it was tension or compression and so on. As shown in Figure 14 and in the same way is used in the United States. We can see this type of welding in ACI Journal and according to the shapes, types and the method of welding as shown in Figures 14, 15 and 16.
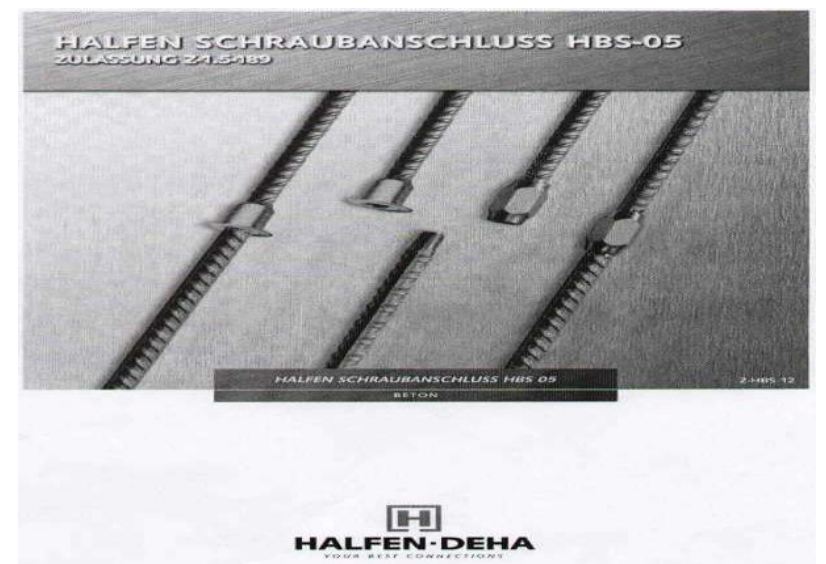

Fig. 14. Shows a German catalogue that deals with mechanical joint

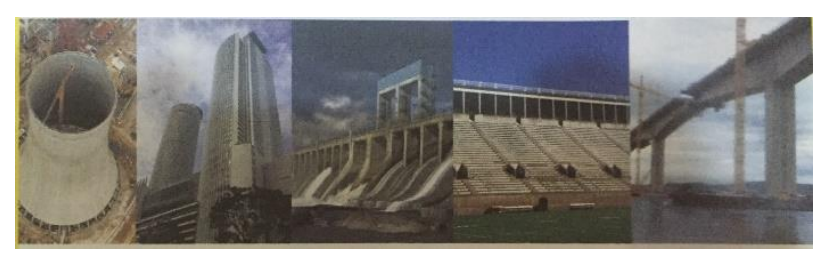

Fig. 15. Shows concrete structures constructed by using mechanical joints in the steel reinforcement [7]

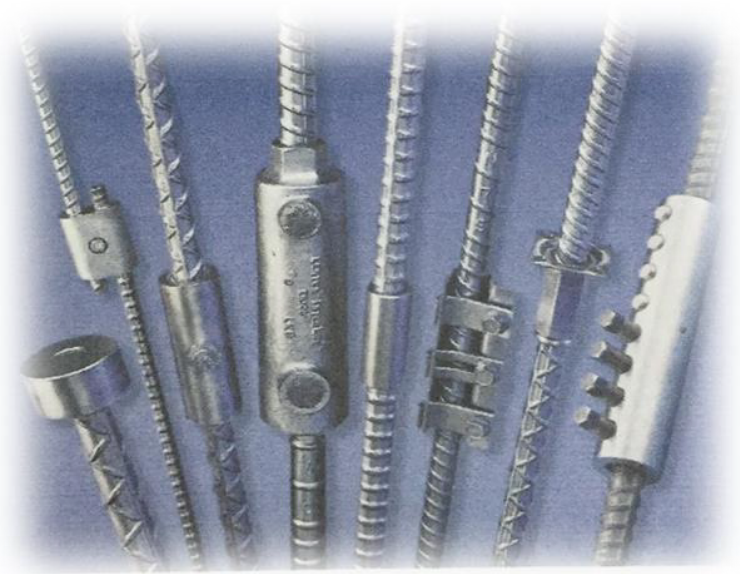

Fig. 16. Shows some shapes and types for mechanical joints [7]

ICC Evaluation Service, Inc. has performed tensile and compression (Static and Dynamic) on the mechanical joint its different types when the steel nut is poured with it in the field, and the results from these tests referred to the success and readiness for these samples and the possibility of many uses in buildings and different manufactural structures. The nuts are made in different locations in the world like United Arab Emirates as there are factories for steel manufacturing by using the welding method.

\section{Test results}

As mentioned before, the mail aim of this research is to study failure behaviour for tested steel bars reinforcement and comparison it with the same main bars without connection. This tables and figure shows results for each tested deferent steel bar connections as shows in tables 4, 5, 6 and 7 and the figure 17 shows the summary.

Table 4. For Steele bar 20mm diamètres

\begin{tabular}{|c|c|c|c|c|c|}
\hline $\begin{array}{c}\text { Sem } \\
\text { ple } \\
\text { no. }\end{array}$ & $\begin{array}{c}\text { Nomi } \\
\text { nal } \\
\text { dia. } \\
\mathbf{m m}\end{array}$ & $\begin{array}{c}\text { Mechan } \\
\text { ical } \\
\text { joint } \\
\text { tensile } \\
\text { strength } \\
\text { test } \\
\text { MPa }\end{array}$ & $\begin{array}{c}\text { Compl } \\
\text { ete bar } \\
\text { tensile } \\
\text { strengt } \\
\text { h test } \\
\text { MPa }\end{array}$ & $\begin{array}{c}\text { *Elongat } \\
\text { ion \% } \\
\text { for } \\
\text { mechani } \\
\text { cal joints }\end{array}$ & $\begin{array}{c}\text { Compar } \\
\text { e } \\
\text { between } \\
\text { Mechan } \\
\text { ical } \\
\text { joint } \\
\text { and } \\
\text { Complet } \\
\text { e bar } \\
\text { tensile } \\
\text { strength }\end{array}$ \\
\hline 1 & 20 & 560 & 550 & 0.00280 & close \\
\hline 2 & 20 & 540 & 570 & 0.00295 & close \\
\hline 3 & 20 & 555 & 570 & 0.00270 & close \\
\hline 4 & 20 & 550 & 540 & 0.00285 & close \\
\hline 5 & 20 & 565 & 535 & 0.00300 & close \\
\hline 6 & 20 & 550 & 540 & 0.00270 & close \\
\hline * Min. elongation & & & & & \\
\hline
\end{tabular}

* Min. elongation $=9 \%$ according to ASTM A $615-05[2]$ for bars dai. $20 \mathrm{~mm}$ 
Table 5. For Steele bar $22 \mathrm{~mm}$ diamètres

\begin{tabular}{|l|l|l|l|l|l|}
\hline $\begin{array}{l}\text { Sampl } \\
\text { e no. }\end{array}$ & $\begin{array}{l}\text { Nomin } \\
\text { al dia. } \\
\text { mm }\end{array}$ & $\begin{array}{l}\text { Mechanic } \\
\text { al joint } \\
\text { tensile } \\
\text { strength } \\
\text { test MPa }\end{array}$ & $\begin{array}{l}\text { Complet } \\
\text { e bar } \\
\text { tensile } \\
\text { strength } \\
\text { test } \\
\text { MPa }\end{array}$ & $\begin{array}{l}\text { *Elongati } \\
\text { on \% for } \\
\text { mechanica } \\
1 \text { joints }\end{array}$ & $\begin{array}{l}\text { Compare } \\
\text { between } \\
\text { Mechanic } \\
\text { al joint } \\
\text { and } \\
\text { Complete } \\
\text { bar tensile } \\
\text { strength }\end{array}$ \\
\hline 1 & 22 & 580 & 590 & 0.00267 & close \\
\hline 2 & 22 & 570 & 570 & 0.00266 & close \\
\hline 3 & 22 & 595 & 570 & 0.00260 & close \\
\hline 4 & 22 & 600 & 560 & 0.00265 & close \\
\hline 5 & 22 & 560 & 545 & 0.00255 & close \\
\hline 6 & 22 & 550 & 565 & 0.00266 & close \\
\hline
\end{tabular}

Table 6. For steel bar $25 \mathrm{~mm}$ diameter

\begin{tabular}{|l|l|l|l|l|l|}
\hline $\begin{array}{l}\text { Sampl } \\
\text { e no. }\end{array}$ & $\begin{array}{l}\text { Nomin } \\
\text { al dia. } \\
\text { mm }\end{array}$ & $\begin{array}{l}\text { Mechanic } \\
\text { al joint } \\
\text { tensile } \\
\text { strength } \\
\text { test MPa }\end{array}$ & $\begin{array}{l}\text { Complet } \\
\text { e bar } \\
\text { tensile } \\
\text { strength } \\
\text { test } \\
\text { MPa }\end{array}$ & $\begin{array}{l}\text { *Elongati } \\
\text { on \% for } \\
\text { mechanica } \\
1 \text { joints }\end{array}$ & $\begin{array}{l}\text { Compare } \\
\text { between } \\
\text { Mechanic } \\
\text { al joint } \\
\text { and } \\
\text { Complete } \\
\text { bar tensile } \\
\text { strength }\end{array}$ \\
\hline 1 & 25 & 610 & 620 & 0.00226 & close \\
\hline 2 & 25 & 600 & 595 & 0.00222 & close \\
\hline 3 & 25 & 595 & 580 & 0.00240 & close \\
\hline 4 & 25 & 610 & 585 & 0.00227 & close \\
\hline 5 & 25 & 590 & 640 & 0.00213 & close \\
\hline 6 & 25 & 615 & 600 & 0.00216 & close \\
\hline
\end{tabular}
$25 \mathrm{~mm}$

Table 7. For steel bar $32 \mathrm{~mm}$ diameter

\begin{tabular}{|l|l|l|l|l|l|}
\hline $\begin{array}{l}\text { Sampl } \\
\text { e no. }\end{array}$ & $\begin{array}{l}\text { Nomin } \\
\text { al dia. } \\
\text { mm }\end{array}$ & $\begin{array}{l}\text { Mechanic } \\
\text { al joint } \\
\text { tensile } \\
\text { strength } \\
\text { test MPa }\end{array}$ & $\begin{array}{l}\text { Complet } \\
\text { e bar } \\
\text { tensile } \\
\text { strength } \\
\text { test } \\
\text { MPa }\end{array}$ & $\begin{array}{l}\text { *Elongati } \\
\text { on \% for } \\
\text { mechanica } \\
1 \text { joints }\end{array}$ & $\begin{array}{l}\text { Compare } \\
\text { between } \\
\text { Mechanic } \\
\text { al joint } \\
\text { and } \\
\text { Complete } \\
\text { bar tensile } \\
\text { strength }\end{array}$ \\
\hline 1 & 32 & 580 & 600 & 0.00234 & close \\
\hline 2 & 32 & 570 & 590 & 0.00258 & close \\
\hline 3 & 32 & 615 & 600 & 0.00249 & close \\
\hline 4 & 32 & 590 & 610 & 0.00248 & close \\
\hline 5 & 32 & 580 & 610 & 0.00283 & close \\
\hline 6 & 32 & 630 & 580 & 0.00199 & close \\
\hline \\
* Min. elongation $=9 \%$ according to ASTM A $615-05[2]$ for bars dai. \\
$32 \mathrm{~mm}$
\end{tabular}

\section{Conclusions and recommendations}

Based on the results of the experimental tests the following are obtained:

1. The results were very close for the reinforcing bar specimens with mechanical joints and those without joints, for the same type of reinforcing bars. Therefore, from the researcher's point of view, it is safer to be used within the required global specifications, based on the ratio of specimen length to the bar diameter according to the American standards.

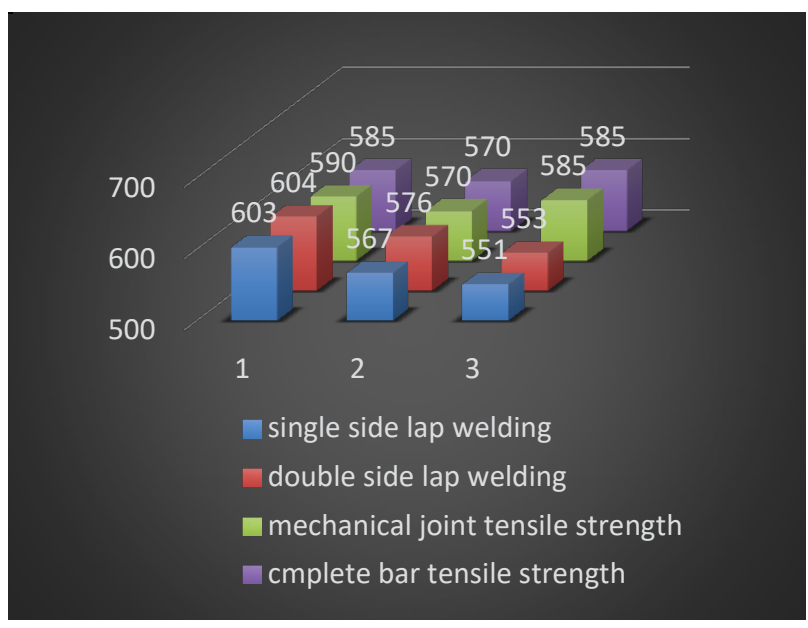

Fig.17. shows deferent results for each tested steel bar connections

2. The mechanical bonding method is relatively easy and quick to implement and configure.

3. The cost of this method is relatively low because it saves some quantities of reinforcing bars.

4. It saves areas and distances between reinforcing bars in concrete walls and lintels with congested reinforcement.

\section{References}

1. National Standard of the People's Republic of china, Code of Design of concrete Structures (GB 500102002).

2. ASTM A615/A615M-05a, "Standard Specification for Deformed and Plain Billet-Steel Bars for Concrete Reinforcement," ASTM Committee A01 on Steel, Stainless Steel, and Related Alloys, West Conshohocken, United States, 2005, 5 pp.

3. Steel designers manual 5 th edition chapter 24 p.677 bolt welds

4. Building Code Requirement for Structural Concrete and Commen Tory ACI-318m-05chapter 12 p.211

5. Building Code Requirement for Structural Concrete and Commen Tory ACI-318m-05 chapter 21 p.311

6. Design of concrete structures edition 13 th chapter 5 p.195.

7. The Magazine of the American Concrete Institute International technical society, December 2013/vol. 35 No. 12. 